certain of its great and important tracts, his specialist knowledge seized and directed in the service of might rather than right. $\mathrm{He}$ sees ideals overthrown and reason treated with contempt. He sees freedom of speech threatened and the visions of democracy spurned. He sees education itself made subservient to ignoble ends, and he asks sometimes what he as an individual or as a member of an association can do when values become so twisted and the world appears to move towards such disastrous ends. The man of science, said Mr. Maccall, believes in the methods of reason and freedom. The technical institution, despite the charge which is sometimes made of narrow specialisation, would fail to be seientific if specialisation produced ignorance of the ways and aims of mankind. Students must be trained to think clearly not only about the special subjects, but also about the relationship of those subjects to a world contracted and spanned by wire. less, by the cinema and by the internal combustion engine. Citizenship is a matter of scientific thinking just as much as any more obviously scientific sub. ject.

The resolutions debated and passed by the Con. ference included one which urged the development of full-time and part-time day courses in technical education rather than the present system in which so much technical work is done in the evening. Other resolutions dealt with overtime and the shift system, the school leaving age, recruitment in industry and the extension of technical education. In connexion with the latter, the Conference welcomed the policy of the Government, which is to make increased financial provision, but asked that in the allocation of financial assistance, special regard be had to the needs of depressed areas.

Mr. John Sargent, director of education for Essex, addressed the closing meeting of the Conference. He outlined the policy which is guiding the development of technical education in Essex-a county which was once largely rural and in which areas are now rapidly becoming industrialised. The first step in connexion with that policy is to create four large technical colleges. Their buildings, as well as their curriculum and organisation, have been designed to give the greatest flexibility. The old idea of one industry dominating one area would in the future be avoided. In places like Dagenham, for example, there are new and diversified industries. They can therefore look forward to an escape from the general depression which devastates a 'one industry' area when that one industry falls upon evil days.

\title{
Sea Fisheries of Europe
}

$\mathrm{O}$ NE of the most valuable of the various publications of the Conseil Permanent International pour l'Exploration de la Mer is its Statistical Bulletin, in which are tabulated the statistics relating to the sea fisheries of all the maritime countries of northern and western Europe. Such ample and diverse data require much time and labour to assemble and work up; vol. 23*, which has just appeared, presents the data for the year 1933. For the use of those whose interest in the work and welfare of the great fishing industries may exceed their ability to interpret detailed tabular data, a very comprehensive yet extremely lucid summary of the statistical tables is given.

The British reader, unfortunately, will derive but little comfort from the tale this Bulletin has to tell. The total quantity of fish landed by all the countries concerned-from Norway to Portugal-was greater by some 200,000 tons (about 6 per cent) in 1933 than in 1932. It was 5 per cent less than the 1930 yield (the highest on record) but 26 per cent greater than in 1913-the last normal pre-War year. Unfortunately, Great Britain has no share in this increase. Both absolutely and relatively, English and Scottish landings have fallen sharply. The English landings, though only very little smaller in 1933 than in 1932 , showed nevertheless a decrease of no less than 15 per cent on pre-War figures. In Scotland the fall has been even greater. In 1933, Scottish landings diminished by 12 per cent as compared with 1932 , and by as much as 36 per cent as compared with 1913 .

A very different state of affairs is revealed in Norway, Germany and Iceland, each of which has had a very marked increase. In fact, almost every

* Bulletin Statistique des Peches Maritimes des Pays du Nord et de l'Ouest de L'Europe. Vol. 23 (pour l'année 1933). (Copenhague : Andr. Fred Høst et Fils, 1935.) Kr. 3,00. important fishing country except Great Britain shows increased landings in recent years. The accompanying table of the total quantity of fish landed (in thousand tons) is highly illuminating, though somewhat dis. quieting from the British point of view.

$$
\overbrace{1913 \quad 1931}^{\text {Total Quantity }}
$$

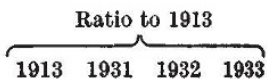

$\begin{array}{llrrrrrrrr}\text { Iceland } & \ldots & 92 & 311 & 288 & 328 & \mathbf{1 0 0} & 338 & 313 & 35 \\ \text { Germany } & \ldots & \mathbf{1 8 1} & 370 & \mathbf{3 5 3} & 387 & \mathbf{1 0 0} & 204 & \mathbf{1 9 5} & \mathbf{2 1} \\ \text { Norway } & \ldots & \mathbf{7 3 2} & \mathbf{8 4 3} & \mathbf{1 0 1 9} & \mathbf{1 1 6 2} & \mathbf{1 0 0} & \mathbf{1 1 5} & \mathbf{1 3 9} & 15 \\ \text { France } & \ldots & \mathbf{1 9 3} & \mathbf{2 4 7} & \mathbf{2 6 2} & \mathbf{2 7 7} & \mathbf{1 0 0} & \mathbf{1 2 8} & \mathbf{1 3 6} & \mathbf{1 4} \\ & & & & & & & & & \\ \text { England } & \ldots & 821 & \mathbf{7 5 2} & \mathbf{7 0 2} & \mathbf{6 9 8} & \mathbf{1 0 0} & \mathbf{9 2} & \mathbf{8 6} & \mathbf{8} \\ \text { Holland } & \ldots & \mathbf{1 4 7} & \mathbf{1 6 8} & \mathbf{1 1 6} & \mathbf{1 1 1} & \mathbf{1 0 0} & \mathbf{1 1 4} & \mathbf{7 9} & \mathbf{7 6} \\ \text { Scotland } & \ldots & \mathbf{3 9 8} & \mathbf{2 6 3} & \mathbf{2 9 2} & \mathbf{2 5 5} & \mathbf{1 0 0} & \mathbf{6 6} & \mathbf{7 3} & 6\end{array}$

The fishing grounds from which the fish are drawn extend from Bear Island to Morocco ; but the North Sea still retains its position as "the most interesting, the most important and the most productive" of them all. From 1924 until 1933, the North Sea yielded on an average about $1,155,000$ tons of fish a year. 1,171,000 tons were landed in 1933-8 quantity which was exceeded only twice in the ten. year period. Relative to the grand total of fish from all grounds, however, the North Sea's contribution is tending to fall slightly. This is due not to any actual decrease in its own productivity, but to in. creased landings from elsewhere. Over the ten years 1924-33, the North Sea yielded an average of $34 \cdot 4$ per cent, or a little more than one third of the grand total. But in 1924 it yielded 39.7 per cent, whereas in 1933 the proportion had dropped to 31.7 per cent.

That the North Sea maintains its yield is a satis. factory condition little expected by the prophets of twenty years ago. Nevertheless, the constancy of the yield is quantitative only ; qualitatively, considerable change of a disturbing kind has taken place. 
The average size of certain important fishes, for example, plaice, soles and haddocks, in the North Sea landings has been materially-perhaps even alarmingly-reduced. In other words, an increased proportion of the eatches now consists of small fish. For full details of this and other changes in the nature of the landings the reader must consult the tables as set out in extenso in the Bulletin. But certain important details concerning the North Sea plaice may be usefully included here.

It is now generally known that the percentage of small plaice landed in England fell rapidly during the Great War. From 45-50 per cent in the immediate pre-War years, it dropped to 24 per cent in 1915 and even fell so low as 7 per cent in 1919. After that year, it rose again, and has kept a steady average of about 70 per cent from 1925 onwards. Thus, during the War and for several years afterwards, the English market was supplied with plaice larger on an average than either before or afterwards. Temporary abandonment of 'small fish' grounds is not regarded by the compiler of the Bulletin as a satisfactory explanation of this; nor does he regard with favour the more usual suggestion that the North Sea plaice had a respite from too intensive fishing during the War so that a larger number lived longer, grew bigger and eventually came into the market until the accumula. tion dwindled. On this point, attention is directed to the significant fact that, in England, the proportion of small plaice began to fall in the year 1914, before any great restriction of fishing grounds had taken place and long before the fish on any closed area had had time to grow. It is interesting to note that the haddock showed no sign of any post-War period of comparatively large fish, that is, there was no benefit from partial closure of the North Sea grounds.

With regard to the other plaice-producing countries, we find that in the seven years 1907-13 the mean percentage of small plaice was 47 per cent in England; 83 per cent in Germany ; 87 per cent in Holland. In the seven years 1927-33 the corresponding figures are given as 74 per cent, 90 per cent and 95 per cent. Whatever be its cause or causes, this great increase in the percentage of small plaice-and other fishes-in the North Sea catches is a phenomenon the effect of which on the future of the fisheries of Great Britain and other countries seems likely to be of extreme importance.

\section{Uplift Pressure on Dams}

$\mathrm{W}^{\mathrm{u}}$ EN a dam is built on porous strata such as generally exist at the beds of rivers, there is a flow through these porous strata under the masonry from the upstream to the downstream side. Accom. panying this, there will be a pressure acting upwards on the masonry floor. An accurate knowledge of this uplift pressure and of the nature of its distribution is of fundamental importance for the purpose of designing a dam. There have been many attempts to investigate by direct measurements from models the way in which this pressure varies with different forms of design.

The usual method of building a tank provided with holes for manometers and filled with sand to represent the subsoil strata and of arranging a model of the dam with a suitable head of water upstream involves a very large number of readings, and is most laborious. Observing the analogy between Ohm's law for the conduction of electricity and Darcy's law for the conduction of water through porous media, N. N. Pavlovsky in 1921 suggested that an electrical method could be employed for studying the subsoil pressures under dams (Proceedings of the International Congress on Dams, 1933). In a paper to the Indian Academy of Sciences (Proc., 2, No. 1, July 1935), Mr. G. Ram, Dr. V. I. Vaidhianathan and Dr. E. McKenzie Taylor, of the Irrigation Research Institute, Lahore, have described their investigations and the methods and apparatus used in determining to what extent this suggestion could be made the basis of a successful attack on the problem of subsoil flow under dams.

In the several cases examined of simple impervious floors with and without sheet piling, the curves obtained by the direct and the indirect methods and by theoretical calculations agreed so closely as to give support to the claim of the authors that the indirect electrical method is trustworthy. They consider that earlier failures have been due to faulty technique, and assert that the fact that the potential distribution in conductors has been shown to be of the same form as the pressure distribution in the subsoil under dams, establishes the mathematical foundation for designs of these works, and, as such, should be considered a great advance on our existing knowledge.

\section{Educational Topics and Events}

BIRmingham.-The Poynting chair of physics, which will be vacated by the retirement at the end of the present session of Prof. S. W. J. Smith, is to be filled by the appointment of Dr. M. L. Oliphant, assistant director of research in physics at the Cavendish Laboratory, Cambridge.

Mr. J. W. Drinkwater has been appointed lecturer in mechanical engineering.

Cambridge.-C. H. Thompson, Queens' College, has been appointed Gurney lecturer in forestry, and J. H. Lockhead, Christ's College, University demonstrator in zoology.

In its annual report, the Committee of Management of the Scott Polar Research Institute states that the Oxford University Expedition to North East Land before its departure, and the Oxford University Ellesmere Land Expedition 1934-35, since its return, have both made use of the facilities of the Institute, which have also been of service to the forthcoming Cambridge expeditions to Iceland, members of which have been at work for some time in the library and map room.

Durham.-At the Convocation to be held on June 30 , the honorary degree of D.Sc. will be conferred on Mr. G. S. Baker, superintendent of the William Froude Laboratory at the National Physical Laboratory, and the honorary degree of D.Litt. on Mr. Robert Steele, editor of the works of Roger Bacon and other medieval literature.

OxFord.-On June 6, the honorary degree of D.Litt. was conferred on Mr. E. A. Lowe, University reader in palæography. At Encænia on June 24, the honorary degree of D.Sc. will be conferred on Prof. E. D. Adrian, Foulerton research professor of the Royal Society. Among those who will then receive honorary degrees of D.C.L. are Prof. Gilbert Murray and $\mathrm{Mr}$. Anthony Eden. 